\title{
Research on Reform and Practice of Public English Teaching Evaluation in Higher Vocational Colleges
}

\author{
Bi Lihua \\ Jinan Engineering Vocational and Technical College, 250200, Jinan, Shandong
}

Keywords: Reform; Public English Teaching Evaluation; Higher Vocational Colleges

\begin{abstract}
In the current higher vocational English teaching, due to the influence of classroom teaching mode, classroom teaching cannot provide students with sufficient opportunities for language practice. The rich and colorful classroom and extracurricular activities can create more opportunities for students to communicate in English, and can organically connect the classroom learning with daily life to achieve the purpose of learning. College English curriculum holds the concept of "service and employment oriented, production, study and research combined", and ultimately improves the employment ability and professional quality of students. In the course of teaching, it is necessary to not only cultivate students' necessary knowledge of English language, but also cultivate students' ability to use English to carry out related business work.
\end{abstract}

The final examination of a test paper is very difficult to reflect the students' learning attitude and the ability to solve the problem, therefore, changing from the mode of one-time final exam, to test in stages, and from "I have to learn" to "I want to learn". The students' attitude and ideas reflected in questions, assignments, tests and oral tests should be carefully recorded, appropriately added, and reflected in their ordinary grades.

\section{Introduction}

A good form of assessment will enable students to clearly learn the purpose and direction of learning, and stimulate students' enthusiasm for learning and self-motivation. In the reform of evaluation mode, it should be clear that the teaching evaluation should not only be evaluated by the concept problem, but also the students should be evaluated with the "task" based on the working process. The traditional "knowledge assessment" should be changed to the overall "ability assessment" for the students. The form of assessment can be introduced into comprehensive project assessment, job site assessment, routine assessment, question and answer assessment in class, attendance management assessment and so on. To make the examination more effective, more comprehensive and more accurate to evaluate the students' learning quality, and to promote the students to study independently and actively, and to stimulate the interest and enthusiasm of the students to further study. As an auxiliary means of English teaching, these activities have an irreplaceable and active role in the proficiency and flexibility of the students' English language knowledge. It is beneficial to cultivate students' initiative in learning English, to cultivate their independent learning ability and innovative spirit, and to consolidate their knowledge and broaden their horizons. It is a research subject worthy of our exploration and has broad space.

\section{Current Situation of the Study}

The breakthrough of higher education reform is the modern vocational education system and the cultivation of skilled talents. The direction of the Ministry of education's transformation of colleges and universities has been clear. 600 of the 1200 colleges and universities in the state's ordinary institutions of higher learning will be transformed into vocational education. In addition to the increase in quantity, the future higher vocational education pays more attention to the development of connotation, emphasizing the characteristics of professionalization is the most important part of the development of higher vocational education. English course in higher vocational colleges is a public 
compulsory course centered on employment, aiming at improving the quality of talents and taking vocational ability and professional quality as the core. The basic requirements for the teaching of English courses in higher vocational colleges should be made clearly. It is necessary for students to master certain basic knowledge and skills of English, to have the ability to listen, speak, read, write and translate, and to read and translate English business information with the help of a dictionary, and make simple words and books in the daily activities and business activities of foreign communication, which lays the foundation for further improvement of English communicative competence in the future.

Assessment is one of the important factors to evaluate the quality of personnel training, and also an important index and method to evaluate the quality of personnel training. The assessment focuses on the teaching achievement, but also plays a guiding role in the teaching orientation. The ratio of the traditional process evaluation and the outcome evaluation of 3:7 makes the students light the final term, which is generally "a test result". This kind of assessment model has a lot of disadvantages, most students think that the exam is "rote memorization", "death to move hard cover". The students "study for the test", the overall knowledge cover narrow, the ability is not comprehensive, the practical ability is poor. This evaluation mode unfavorable to mobilize students' learning enthusiasm, is not conducive to promoting the development of students' creative thinking, It is difficult for students to integrate the knowledge they have learned and apply them to practical problems in practice.

\section{The Design for Public English Teaching Evaluation in Higher Vocational Colleges Can be Divided into Four Parts}

Changing a single assessment method to a diversified assessment and evaluation method. The final examination results of the final examination of College English courses are made up of the final examination papers and the examination methods integrated into the daily teaching. They are examined in five aspects, such as oral, listening, translation, reading and writing, in order to promote the improvement of students' English overall ability.

The speaking test and listening test are integrated into the daily classroom teaching, and the students' speaking and listening skills are assessed through speeches, dialogues, plays, debates and other forms. The translation, writing and reading test is conducted through the examination paper.

Finally, through the combination of these tests, the students' English learning and application ability are comprehensively evaluated.

\section{The Specific Measures for Implementation}

The routine work, attendance management assessment will be included in the normal assessment.

Practical operation and effect: after each unit is finished, a written assignment is arranged. The assessment is divided into 5 grades according to the quality of the work: A + (English writing is good, clean and absolutely right), A (English writing is neat, clean and absolutely right), A - (English writing is neat, clean, but the individual words spelling mistakes or grammar errors), B (scrawled in written English, or more than 3 spelling and grammar errors), C (incomplete). The number of absence is more than 3 times per semester, the average score is zero. It is more comprehensive, more effective and more accurate to evaluate the students' learning quality in the ordinary, more can promote students' active learning, more conducive to stimulate students' interest in learning English and enthusiasm.

At present, college English teaching mainly focuses on classroom teaching, attaches great importance to reading and writing training, and ignores the ability of listening and speaking. In order to change the present situation of the dumb English teaching and cultivate the students' ability to communicate in English, we must attach importance to the teaching of oral English and let the students practice repeatedly in the form of dialogue or personal oral expression in the classroom. At the same time, we should pay full attention to oral English test. 
Practical operation and effect: English duty day: 1 people in each class go to the blackboard to write a piece of news English, or a popular English explanation every day. Let students choose a piece of English material in class, write it on the blackboard in advance, speak in English in class, and teach students related language points. Students teach students, not only can arouse students' interest in learning English, but also create a harmonious and joyful English learning environment. Students have great courage and interest. The level of oral English expression will go up naturally. According to the students' English pronunciation, intonation, grammar, and whether the language is in accordance with the habit expression and whether the language is in accordance with the context and the requirements of the foreign language culture, the teacher gives the corresponding marks. In order to mobilize the enthusiasm of students to learn English, students can extempore display their own language skills, such as recitation, speech, singing English songs and so on as a reference score. The level of the students is required: to be able to be proficient and correct in explaining and presenting the materials they have chosen. The language is appropriate, generous and accurate. It is in line with the language habits and cultural habits of the English speaking countries.

Cooperative learning in English is a learning way for students to achieve their learning goals through division and cooperation. Students accomplish their assigned learning tasks through individual efforts and cooperation among team members. Only if the team is successful, can the individual succeed. Cooperative learning emphasizes the learning style of autonomy, cooperation and inquiry, emphasizing the need to change the situation of teachers as the center, and promote the students' active learning and self-development. It's a real push to truly promote the progress of each student by achieving a multi-directional, interactive and diversified information exchange between teachers and students.

Practical operation and effect: each class is divided into 5-6 groups according to the principle of voluntary and appropriate coordination, and each group chooses a responsible student leader. The following activities can be carried out between the group members: cooperative learning texts, cooperative learning words, "discuss" or "debate" activities, group cooperation and dialogue, and team work. This semester's oral English group work is a workplace dialogue. Each group will be divided into two or three people, and they will shoot the workplace dialogue video and upload it to the online course platform. All the teams completed the work on time, and the shooting results and conversational fluency were different, and some groups were re-shot and uploaded.

Increase the scores of usual scores in questions, dictation, recitation and answering questions on the course platform.

Practical operation and effect: classroom questioning is used in group competition, teachers ask questions first, team members answer in the course platform, and the answer team gets a pentagram. Finally, adds points to the corresponding members of the team winner. The teacher releases each unit test questions on the course platform, so that students can prepare and review before class and after class, and the course platform gives immediate feedback. According to the students' answers, the teacher adjusted the teaching content in time. Let each student produce a set of English questions and do a set of English questions. Practice the point of knowledge repeatedly, strengthen and master it. Most students can make a good test, but a very few students can not do a set of English test questions seriously, the situation of coping, or do not write the name in the paper.

The so-called English application class is based on the practical writing of each unit, making English greeting cards, English business cards, English notices, English posters, etc. Let students truly integrate into the English environment.

Practical operation and effect: this semester's application job is to make an English greeting card. After the production is finished, take pictures and upload it to the course platform. Most of the students were well prepared and wrote good wishes to teachers. Individual students' greeting cards do not meet the requirements, because they make greeting cards in Chinese.

\section{Conclusion}

For a long time, College English teaching has always been "Teacher centered", teachers are the main body of classroom teaching activities, and students are passive receivers. Without the initiative 
of students, it is easy to create a boring classroom, which affects the learning enthusiasm of students, and also affects the learning effect. The interpersonal interaction in the study of the reform of college English diversification assessment and evaluation based on practical ability training provides the conditions for communication between students and the communication between students and teachers, so that teachers can give feedback to the students' problems in time. Under the condition of information technology, using the network course platform and English APP to a great extent break through the limitations of traditional classroom teaching, improve the environment of college English teaching, and also change the traditional mode of "teaching and learning", give students more autonomy and operation space, and truly realize the multi-level college English. The stereoscopic and individualized teaching strengthens the students' self-learning ability, improves their interest in English learning, further stimulates the enthusiasm of the students to participate in the teaching process, improves the efficiency of English learning, and improves the students' comprehensive language application ability in an all-round way, especially listening and speaking ability.

\section{References}

[1] Li Fengju. Reform of Teaching Methods of Public English in Higher Vocational Colleges, [J]. Intelligence, 2014 (32): 179.

[2] Yuan Jia. A Study of Public English Teaching in Higher Vocational Colleges from the Perspective of Vocational Ability Training [D]. Hunan Agricultural University, 2015. 